\title{
PROPOSAL FOR INTERVENTION THROUGH REBA FOR THE PREVENTION OF WORK-RELATED OSTEOMUSCULAR DISORDERS (WRMS)
}

\author{
Israel Da Silva Nunes ${ }^{1}$, David Barbosa De Alencar ${ }^{2}$ and Igor Felipe Oliveira Bezerra ${ }^{3}$
}

${ }^{1,2}$ Blauro Cardoso de Mattos Higher Education Institute - FASERRA. Manaus-Amazonas, Brazil.

${ }^{3}$ Nilton Lins University. Manaus-Amazonas, Brazil.

Email: israelengcivil034@gpmail.com; david002870@hotmail.com; igor.bezerra@uninilton.edu.br

Received: Aug 16th 2019

Accepted: Aug 30th 2019

Published: December 02 ${ }^{\text {th }}, 2019$

Copyright (C2016 by authors and Galileo Institute of Technology and Education of the Amazon (ITEGAM).

This work is licensed under the Creative Commons Attribution International License (CC BY 4.0).

https://creativecommons.org/licen ses/by/4.0/

\section{ABSTRACT}

This study presents a bibliographical review about the evaluation of the main complaints of the attendants of a real estate company located in the city of Iranduba/AM. to designate the set of injured musculoskeletal alterations, affected by the workers. To evaluate the main indicative complaints of WMSD. The research was conducted in the internal facilities of the company object of this study. Where a questionnaire was applied with the aid of the REBA tool. The sample of this research was composed by 6 collaborators who work in the company attendance in the morning and afternoon shifts. Data collection took place in June 2019. The data collected through this study indicated important indications of the body regions most susceptible to musculoskeletal disorders related to the profession of attendant.

Keywords: Ergonomics. DORT. Prevention.

\section{INTRODUTION}

This study has as guiding assumption that health increasingly needs investments for its prevention. Given the inadequate working conditions offered to employees in the companies, the International Labor Organization (ILO) has considered the problem as a discussion, and during the last years has made recommendations regarding occupational hygiene and safety, whose objective is to promote the adequacy good working conditions as a way to prevent Work-related Musculoskeletal Disorders (DORT).

In order to understand the practical and theoretical benefits in improving the complexity of the relationship between man and work, the concept of Ergonomics arises, whose purpose is to act directly or indirectly on people's quality of life. Within this context is the relevance of this study, which aims to evaluate the main pain complaints of employees of a company located in the city of Iranduba / AM., Where it will be treated here as Company "X".

Within this scenario emerges the question to be answered in this research: What factors contribute to the emergence of DORT? Thus, this study assumes the objective of making an ergonomic analysis in a real estate company using the ergonomic tool REBA. Within this scenario, it is relevant to take care of the Occupational Safety Engineering professional, who, besides detect or confirm, its function is to alert to the problem and prevalence of problems arising from the profession, presenting prevention strategies and seeking to raise attention to self-care in health.

Since the ergonomic approach proposes prevention measures from what employees do to protect their own health against the risks present in the workplace. In this sense, Maciel et al. (2015) comments that ergonomics has played a fundamental role in preventing workers' conditions, as it allows the evaluation of working conditions and environments, proposals and implementation of technical and administrative solutions, thus reducing the frequency of DORTs.

For the academic this study becomes important, mainly because the world market scenario is increasingly demanding and lacking of qualified professionals, who understand particular aspects that involve the WMSDs. The research will also contribute to the generation of research sources based on data collected in current articles and published works in order to inform the actual practice of Ergonomics in the prevention of DORT's. 


\section{DEVELOPMENT}

This study presents the study about the evaluation of the main pain complaints of Company $\mathrm{X}$ employees, where it is pointed out that the work-related musculoskeletal disorder (DORT), This is the nomenclature currently used most by occupational health and medical researchers to designate a set of injured musculoskeletal changes suffered by workers resulting from their professional practice. [1].

According to Ramos (2014), such disturbances are currently becoming the main cause of removal of workers from their duties in all countries, thus gaining the status of the newest epidemic in the world. In Brazil there are few studies on the prevalence of WMSDs, according to IBGE information, WMSDs are among the most prevalent occupational diseases registered in Brazil.

This lesion can be defined as a work-related syndrome, characterized by the occurrence of various concomitant or not concomitant symptoms, such as pain, paraesthesia, heaviness, and insidious fatigue usually appearing in the upper limbs, but may also affect lower limbs [2].

Among the most common complaints related to WRMS are localized, radiated or generalized pain, discomfort, fatigue, and heaviness. In the most chronic and severe cases, excessive sweating of the hands and allodynia may occur (sensation of pain in response to non-harmful stimuli in normal skin).

Usually the symptoms are insidious in evolution until clearly perceived. It is often triggered or aggravated after periods of increased work or long hours and in general, the worker seeks ways to maintain the development of his work, even at the expense of pain. The decrease in physical capacity is perceived at work and outside of it in daily activities [3].

These are closely related to the fast pace of work, which often has no pauses for recovery, with insufficient rest to compensate for the wear and tear caused by their inadequate working hours, the work of attendants is directly or indirectly causing the development of the work. DORT's [4]. In the studies by Ramos (2014), the author points out that, Among the activities most related to DORTs These include services for workers including telemarketing, cashier, typing, bookkeeping, assembly of small parts and components, footwear, sewing, packaging, telephone operators, treadmills, cooks, cleaning workers, dental assistants. cane cutters, quality control, butler, whip assembler, image pipe assembler, machine operation, computer terminal operation, administration assistant, accounting assistant, telex operation, typing, bricklayer, secretary, administrative technician, kitchen worker, butler, electrician, clerk, cashier, receptionist, janitor, lab helper, tipper and vulcanizer.

The risk factors of WRMS cannot be analyzed independently, as they interact with each other and must always be analyzed in an integrated manner. They involve biomechanical, cognitive, sensory, affective and work organization aspects. For example, organizational factors such as workload and rest breaks can control frequency and intensity risk factors [3].

However, it should be emphasized that the prognosis depends on early diagnosis and treatment and the removal of the work that causes the morbid process, since only in these circumstances is it effective. In the most severe states, injuries are irreversible and disabling and mental distress can be intense. Thus, the workers' lack of information about this disease is a factor that makes its evolution not the best possible, leading to irreversibility with the consequent incapacity for work. Thus, the importance of health professionals to elucidate the worker as much as possible, avoiding superficial or confusing orientations, as the patient may not take his or her disease seriously, due to its insidious onset (RAMOS, 2014).

Although the Unified Health System (SUS), in recent years, has advanced greatly in ensuring citizen access to health care actions, only from 2003 the national policy guidelines for the area began to be implemented [2]. Between the Strategies for the implementation of Comprehensive Occupational Health Care, the implementation of the National Network for Integral Occupational Health Care stands out. The creation of these measures had as its guiding axis, the importance of occupational health for the development of any institution, in this sense physiotherapy is of vital importance and one of the main resources in the treatment of WMSDs [5].

The research was conducted at the internal premises of a real estate company located in the city of Iranduba / AM. Where a questionnaire with 10 objective questions was applied in order to achieve the objectives proposed by this study. The sample of this research was the collaborators who perform the function of attendants in the company object of this study, located in the city of Manaus / AM., It met the Resolution 466/2012 of the National Health Council.

Data collection was performed by capturing images (static and dynamic) of the activities developed during the work of the attendants, using a camcorder and a digital camera. adjusted to capture a profile image of the individual.

The search in electronic databases (SciELO and LILACS) was performed using the terminologies registered in the Health Sciences Descriptors (Decs) created by the Virtual Health Library, namely Ergonomics, Physiotherapy. DORT Prevention. Data analysis and tabulation were performed using Microsoft Office Excel version 2007 software, and the data were expressed as a percentage.

After data collection and analysis, both in the subjective and objective methods, hypotheses were raised about possible occupational risks. The possible diagnosis of the postures acquired by the radio broadcasters, the working conditions, acquired habits, stressful movements and the work organization will guide the discussions of this research.

The real estate agent works in the realization of purchase, sale and administration of real estate. Administrative Assistant's main activity: whose role is to enter contracts, enter and check out the miscellaneous document system, spreadsheet creation, customer receipt, and industry organization.

For the development of this study, it was decided to make use of Rapid Entire Body Assessment (REBA), which was developed by Sue Hignett and Lynn McAtmney, was published in Applied Ergonomics in 2000. This method allows the analysis of the postures adopted in the work, of applied forces, types of movements or actions performed, muscle activity, repetitive work and the type of grip adopted by the worker when performing the work.

a) Division of the body into segments to be individually coded, and evaluates both the upper limbs, the trunk, the cervical spine and the legs.

b) Analyze the repercussion on the postural load and load management performed with the hands and other parts of the body. c) The result determines the level of risk that can cause injuries, establishes the required level of action and the urgency of the interventions.

d) Evaluate the duration of the excessive task and the composition of other elementary operations, secondary to the postures and movements recommended. 
e) Record the different postures adopted by the worker during his workday, and capture in photographs and annotations in real time if possible.

f) Identification among all registered postures, those considered most significant or "dangerous" for subsequent evaluation with the REBA method. g) Completion of the REBA evaluation form.

j) Refer to table A for score.

k) Consultation of the action level, risk and urgency of action corresponding to the calculated final value.

Initially, the activities performed by employees within the company object of this study were analyzed, as follows (Chart 1):

Table 1: Action Plan - Ergonomic Improvements.

\begin{tabular}{|c|c|c|c|}
\hline \multicolumn{4}{|c|}{ SEQUENCE OF TECHNICAL ACTIONS } \\
\hline ACTIVITY & $\begin{array}{c}\text { POSTURE } \\
\text { REQUIREMEN } \\
\text { TS } \\
\end{array}$ & $\begin{array}{l}\text { BODY } \\
\text { PARTS }\end{array}$ & IMAGE \\
\hline $\begin{array}{l}\text { I. Sitting, filling out } \\
\text { spreadsheets is } \\
\text { carried out of } \\
\text { documents. }\end{array}$ & $\begin{array}{c}\text { - Extension }-0^{\circ}- \\
20^{\circ} .\end{array}$ & - Trunk & \\
\hline $\begin{array}{l}\text { II. Sitting performing, } \\
\text { closing the work } \\
\text { plan. }\end{array}$ & $\begin{array}{c}\text { - Flexion }-0^{\circ}- \\
20^{\circ} .\end{array}$ & - Neck & \\
\hline $\begin{array}{c}\text { III. Sitting } \\
\text { performing, closing }\end{array}$ & $\begin{array}{c}\text { - Flexion }-30^{\circ}- \\
60^{\circ} .\end{array}$ & - Legs & \\
\hline $\begin{array}{l}\text { IV. Sitting, } \\
\text { performing various } \\
\text { document analysis. }\end{array}$ & $\begin{array}{c}\text { - Flexion / } \\
\text { Extension - } 0^{\circ}- \\
20^{\circ} .\end{array}$ & - Arms & \\
\hline $\begin{array}{l}\text { V. Sitting performing } \\
\text { light flexing } \\
\text { movements with the } \\
\text { forearms in the } \\
\text { organization of } \\
\text { documents. }\end{array}$ & $\begin{array}{c}\text { - Flexion }-60^{\circ}- \\
100^{\circ} .\end{array}$ & - Forearm & \\
\hline $\begin{array}{l}\text { VI. Sitting, analyzing } \\
\text { work plan, } \\
\text { performing flexion } \\
\text { movements with fists. }\end{array}$ & $\begin{array}{c}\text { - Flexion - } \\
\text { Extension - } 0^{\circ}- \\
15^{\circ} .\end{array}$ & - Fist & \\
\hline
\end{tabular}

Source: Authors, (2019).

The employee of Rama Real Estate Purchase and Sale Eireli performs an administrative function in which the activities applied by him are described in (Table 1) in the activity tab, in the postural requirements tab are placed the angles that serve as parameters for an ergonomic analysis according to tool REBA, In the body parts tab are the components that will be analyzed using the parameters established by the REBA ergonomic tool already described in the requirements tab, given the information contained in (Table 1) it will be possible to say the level of action and the level of risk that the employees of the Rama are exposed. 
Generally, employees in the administrative sector are responsible for entering contracts, entering and writing off the miscellaneous document system, creating spreadsheets, receiving customers, and organizing the industry. Among the main aspects of difficulties described by the interviewees, 100\% $(n=6)$ described wrist discomfort. Following the activity performs:

a) Monitors the flow of contracts in the system;

b) Answer phone calls.

Analyzes were performed using the ergonomic tool REBA (RAPID ENTIRE BODY ASSESSMENT), the employee's analyzed trunk member at the time of the administrative activities already described in this article was within the scoring range 2 where $\rightarrow 0^{\circ}-20^{\circ}$ flexion / extension, the neck limb was within the scoring range $1->00^{\circ}-20^{\circ}$ flexion and the leg limbs were within the scoring range 1 where the position of the collaborator indicated that he was sitting on the bilateral support.

After analyzing the trunk, neck and legs, the same ergonomic tool (REBA) was used to analyze the following limbs; arm, forearm and wrist. The arm was within the range $1 \rightarrow 0^{\circ}-20$ $\circ$ flexion / extension, the forearm was within the range $1->60^{\circ}$ 100 flexions and the wrist were in the range 2,> $15^{\circ}$ flexion / extension.

After analyzing the members of the collaborator's body already described above, the load / force, grip and activity scoring tables determined by the REBA ergonomic tool were used to reach the conclusion that the collaborator is in range 2 as shown in (Table 2).

Table 2: Risk and Action Level - ergonomic improvements.

\begin{tabular}{|c|c|c|c|}
\hline $\begin{array}{c}\text { Action } \\
\text { level }\end{array}$ & Punctuation & $\begin{array}{c}\text { Risk } \\
\text { level }\end{array}$ & $\begin{array}{c}\text { Intervention } \\
\text { and further } \\
\text { analysis }\end{array}$ \\
\hline 0 & 1 & Very low & $\begin{array}{c}\text { It is not } \\
\text { necessary }\end{array}$ \\
\hline 1 & $2-3$ & Low & May need \\
\hline 2 & $4-7$ & Medium & Required \\
\hline 3 & $8-10$ & High & $\begin{array}{c}\text { Required } \\
\text { ready }\end{array}$ \\
\hline 4 & $11-15$ & $\begin{array}{c}\text { Very } \\
\text { high }\end{array}$ & $\begin{array}{c}\text { Immediate } \\
\text { acting }\end{array}$ \\
\hline
\end{tabular}

Source: Authors, (2019).

It was not identified during data collection, productivity pressure and / or fast pace. The administrative assistant works on business hours, meeting the needs of the client, from Monday to Friday from $08 \mathrm{~h}$ to $17 \mathrm{~h}$, Saturdays from $08 \mathrm{~h}$ to $12 \mathrm{~h}$, in compliance with the mandatory workload of $186 \mathrm{hs}$ monthly, 40hs weekly, meeting the CLT regime. The Administrative Assistant's routine does not have intense static movements or sudden upper / lower limbs, trunk, wrist / neck.

According to the company, concerns about pain complaints have been increasing, since this fact comes playing on paper important in the work development process, which can lead to the incapacity and possible death of the employees.

Thus, it is understood that occupational ergonomic management programs can be developed by the company focusing on the organization of work and / or worker. To this end, it was leaving at the premises of the company with the manager, the proposal of an ergonomic improvement action plan, as described below:
Table 3: Action Plan - Ergonomic Improvements.

\begin{tabular}{|l|l|}
\hline $\begin{array}{l}\text { What (improvement to } \\
\text { deploy) }\end{array}$ & $\begin{array}{l}\text { Do not perform sudden } \\
\text { movements during activities / } \\
\text { Maintain posture correction while } \\
\text { sitting while performing the } \\
\text { worksheet filling activity, } \\
\text { Providencia. }\end{array}$ \\
\hline Why (expected results) & $\begin{array}{l}\text { Minimize physical wear, prevent } \\
\text { injuries and illness in the worker. }\end{array}$ \\
\hline Who (responsible) & SESMT \\
\hline When (date) & Immediately. \\
\hline How (procedure) & According to ergonomic analysis. \\
\hline How much (R\$) & x \\
\hline \multicolumn{2}{|c|}{ Source: Authors, (2019). }
\end{tabular}

This plan is justified by the fact that the configuration of the Administrative Assistant's activities is conditioned to perform most of his workday in the sitting position with slight movements of the upper / lower limbs, trunk, neck and wrists. Faced with this scenario the company can make use of physical therapy strategies, thus increasing the frequency and intensity of positive emotional states. However, it is noteworthy that WMSD can be linked to the work environment in which the individual is inserted.

\section{CONCLUSIONS}

Based on the analysis of this study, this study suggests the implementation of a program of Labor Gymnastics (GL), whose objective will be the promotion of health benefits for the attendants. Thus, increasing willingness to work and interaction among colleagues, as well as decreased pain complaints.

But to achieve such benefits, the company and its employees must be aware of the individuals who guide GL. This will consist of trained physiotherapy professionals for proper exercise programming and orientation.

In a final analysis it is discussed that the elaboration of educational programs for the prevention and recurrence of WMSDs through GL, which physics should be directed in order to trigger knowledge, attitudes and behaviors compatible with the area of activity.

\section{ACKNOWLEDGMENTS}

To FASERRA Institution that with its team of education professionals who invested all their resources to offer a quality specialization and especially to my advisor Teacher David Barbosa de Alencar for their trust and my God for another opportunity to get more. a title.

\section{REFERENCES}

[1] Marinho, E.F.; Marinho, D.F. Estudo das principais queixas álgicas indicativas de DORT em professores de educação especial. [Artigo]. Brasília: Ávila, 2013.

[2] Farias, I.M.A. Avaliação da dor e lesões ocasionadas pelo trabalho em cirurgiões-dentistas na cidade de Fortaleza, CE. In: Revista de Fisioterapia, vol. 01, n. 02, pp. 35-41, 2012.

[3] Maeno, Maria [et al.]. Protocolos de atenção integral a saúde do trabalhador de complexidade diferenciada. Brasília: Editora do Ministério da Saúde, 2012. 
[4] Baucke, Oswaldo Jose Severo. Sistemática preventivas e participativa para avaliação ergonômica de quadros lombalgicos: o caso de uma indústria fabricante de dormitórios e cozinhas em MDF. [Dissertação]. Porto Alegre: UFRS, 2008.

[5] Nogueria, S.N.M [et al.]. Atuação fisioterapêutica no processo de reabilitação neuromuscular de distrofia motonica de Steinert: Relato de caso. In: Revista de Pesquisa, vol. 03, n. 03, pp. 222232, 2011.

[6] Brasil. Dor relacionada ao trabalho: distúrbios osteomusculares relacionados ao trabalho (Dort). Brasília: Editora do Ministério da Saúde, 2012.

[7] Sallum, A.M.C.; Garcia, D.M.; Sanches, M. Dor aguda e crônica: revisão narrativa da literatura. In: Acta Enfermagem, número especial, pp. 50-4, 2012.

[8] Santos, R.V.; Musso, S.A. Avaliação da qualidade de vida em trabalhadores de indústria têxtil. In: Perspectiva, vol. 36, n. 134, pp. 163-173, 2012.

[9] Sobral, M.L.P. [et al.]. Estudo da prevalência de algias na coluna vertebral em residentes de cirurgia cardiovascular: estudo inicial. In: Revista brasileira de Medicina do Trabalho, vol. 11, N. 02, pp. 82-9, 2013.

[10] Velho, C.P.; Amaral, D.M. Analise do impacto das atividades laborais na qualidade de vida dos funcionários do setor de enfermagem da unidade de terapia intensiva (UTI) do hospital Governador Celso Ramos. [Monografia]. Biguaçu: Santa Catarina, 2009. 